\title{
Low-level retention forestry, certification, and biodiversity: case Finland
}

\author{
Timo Kuuluvainen ${ }^{1 *}\left(\mathbb{D}\right.$, Henrik Lindberg ${ }^{2}$, Ilkka Vanha-Majamaa ${ }^{3}$, Petri Keto-Tokoi ${ }^{4}$ and Pekka Punttila ${ }^{5}$
}

\begin{abstract}
In managed forests, leaving retention trees during final harvesting has globally become a common approach to reconciling the often conflicting goals of timber production and safeguarding biodiversity and delivery of several ecosystem services. In Finland, the dominant certification scheme requires leaving low levels of retention that can benefit some specific species. However, species responses are dependent on the level of retention and the current low amounts of retention clearly do not provide the habitat quality and continuity needed for declining and redlisted forest species which are dependent on old living trees and coarse woody debris. Several factors contribute to this situation. First, the ecological benefits of the current low retention levels are further diminished by monotonous standwise use of retention, resulting in low variability of retention habitat at the landscape scale. Second, the prevailing timber-oriented management thinking may regard retention trees as an external cost to be minimized, rather than as part of an integrated approach to managing the ecosystem for specific goals. Third, the main obstacles of development may still be institutional and policy-related. The development of retention practices in Finland indicates that the aim has not been to use ecological understanding to attain specific ecological sustainability goals, but rather to define the lowest level of retention that still allows access to the market. We conclude that prevailing retention practices in Finland currently lack ecological credibility in safeguarding biodiversity and they should urgently be developed based on current scientific knowledge to meet ecological sustainability goals.
\end{abstract}

Keywords: Boreal forest, Ecological sustainability, Legacy structure, Forest dynamics, Forest certification, Forest structure, PEFC certification

\section{Background}

In managed forests, leaving retention trees has globally become a mainstream approach to reconciling the often conflicting goals of timber production, conservation of biodiversity, and provisioning of other ecosystem services (Franklin et al. 1997, Lindenmayer et al. 2012). Leaving retention trees typically aims at maintaining some of the key structures of native forest ecosystems (Gustafsson et al. 2010, 2012; Lindenmayer et al. 2012). Often, the purpose is to provide habitat continuity for species and thus safeguard biodiversity. The goal may also be to maintain esthetic values, such as scenery, and recreational possibilities (Gustafsson et al. 2012), or specific processes such as carbon sequestration.

\footnotetext{
* Correspondence: Timo.Kuuluvainen@Helsinki.fi

${ }^{1}$ Department of Forest Sciences, University of Helsinki, P.O. Box 27, Fl-00014 Helsinki, Finland

Full list of author information is available at the end of the article
}

Retention practices and levels vary remarkably, from leaving only individual trees up to leaving $15 \%$ or even $40 \%$ of trees (Beese et al. 2019; Scott et al. 2019; Shorohova et al. 2019). In the Northern European countries, very low retention levels are used (Gustafsson et al. 2012). As an example, an average of only $1.2 \%$ of stand volume was retained in living retention trees in the years 2013-2017 in the private forests of Finland, as certified by the Finnish Programme for the Endorsement of Forest Certification (PEFC) certification standard (Finnish Forest Centre, 2019).

The motives and reasons for introducing retention can be diverse. These include traditional biodiversity-related motives, such as "lifeboating" habitats and species over the forest regeneration phase and enhancing forest structural variation and landscape connectivity (Franklin et al. 1997). In the Fennoscandian boreal forest, an important goal of retention is to provide continuity of old 
living trees and coarse woody debris (CWD) as crucial habitats for declining epiphytic and saproxylic species (Äijälä et al. 2019). In addition, leaving retention trees in clearcut tracts was hoped to improve the negative public image associated with clearcutting. From a forestry point of view, following certification criteria may secure the access of wood products to the environmentally conscious market.

Recently, retention forestry has been extensively discussed and reviewed from the ecological point of view and from local to global scales. These reviews are either narrative ones (Gustafsson et al. 2010, 2012; Lindenmayer et al. 2012) or reviews using quantitative meta-analysis tools (Rosenvald and Lõhmus 2008; Fedrowitz et al. 2014; Mori and Kitagawa 2014; Soler et al. 2015). In general, the former reviews present retention forestry in a positive light, while the latter quantitative analyses reveal both the pros and cons of the approach.

In North America, Australia, South America, and Tasmania, the retention approach has become a common practice in forestry during recent decades (Work et al. 2003; Aubry et al. 2004; Martínez Pastur et al. 2009; Baker and Read 2011; Beese et al. 2019; Scott et al. 2019). In Fennoscandia, more or less experimental studies on the ecological effects of varying retention levels have been carried out (Vanha-Majamaa and Jalonen 2001; Vanha-Majamaa et al. 2007; Kruys et al. 2013; Johnson et al. 2014). However, quantitative holistic cross-biome evaluations of the performance of the retention approach are largely lacking (but see Mori and Kitagawa 2014).

In Fennoscandia, forestry has since the 1950s been mainly based on the complete removal of forest standing stock in standwise final harvests through clearcutting. Despite currently available alternative harvesting methods, such as continuous cover forestry (Pommerening and Murphy 2004), clear felling is still the prevailing method in Fennoscandia. Forest stands and thus also clearcuts are typically $1-10$ ha in size. The minimum number of retention trees per hectare has ranged from five previously in Finland to the current level of 10 trees in Finland, Norway, and Sweden. As a result of intensive forestry and the clearcutting practice, more than $90 \%$ of all productive forest land in Finland and Sweden is covered by structurally simplified, even-aged, and evenstructured stands (Gustafsson et al. 2010). Since the 1990s, the increasing negative ecological and esthetic outcomes of intensive forestry have led to wide-scale introduction and research of the retention approach (Simonsson et al. 2015).

The extensive use of the retention approach into practical forestry has taken place in different ways, on a voluntary basis, through certification standards and legislation. For example, in Sweden, retention is required by the Forestry Act (Simonsson et al. 2015), while in Finland leaving retention trees is required by the PEFC certification standard prevailing in private and stateowned forests, and by the Forest Stewardship Council (FSC) certification standard prevailing in company forests. It is important to note that retention is a central component of certification schemes and as such an elementary part of a marketing instrument aimed at guaranteeing access of forest industry products to the market. In theory, this should result in leaving sufficient retention to credibly safeguard biodiversity in managed forests (Gustafsson et al. 2010, 2012).

Recently, some review papers have suggested retention as a general approach and solution for ecologically sustainable forestry on a global scale (Gustafsson et al. 2010, 2012; Lindenmayer et al. 2012). Here, we present a critical account of retention forestry in general and in Fennoscandia in particular. While acknowledging the positive effects of leaving retention in general, our aim here is to point out some general problems and weaknesses in forest management with low levels of retention. Our focal area is Fennoscandia and we take Finland as a case to examine how these problems exist in practice. Our point of view is ecological and biodiversityorientated. Importantly, our aim is not to discredit the retention approach as such, but to contribute to a more rigorous and ecologically effective use of the retention approach in rapidly changing future conditions.

The terminology associated with retention is diverse (Simonsson et al. 2015). We use (tree) retention as a general term, including all activities when standing trees are left unharvested in forestry operations for noncommercial reasons. Retention can be divided into green (tree) retention and dead (tree) retention. We use the term low (level) retention when the amount of retention is below $2 \%$ of standing tree volume.

\section{Ecological and management challenges of retention practice}

The ecological challenges of retention practices are largely related to the fact that in many regions retention was introduced and developed to be an instrument ensuring the access of forest products to the market by assuring that forestry practices do not destroy forest ecosystems and their biodiversity. However, defining and verifying ecological sustainability is tricky. This opens the playground for many kinds of interpretations. Instead of asking how much is enough to safeguard biodiversity, the question from the forestry revenues point of view may be how low retention can be and still maintain access to the market (see Finland case below).

Recent ecological literature on retention also contains some controversial views. For example, in their review paper, Gustafsson et al. (2012) claimed that "Retention is 
an alternative to clearcutting." Leaving small numbers of retention trees per hectare $(5-10)$, which has been the most common practice in Fennoscandia, does not change the fact that most of the harvested area (stand) is clearcut. Thus it has been defined that low-level retention $(<2 \%)$ is not considered retention forestry but clearcutting (Fedrowitz et al. 2014). One can ask if low retention is used as a "band-aid fix" with minor ecological benefits, but which allows the underlying status quo of ecologically unsustainable clearcutting system to be continued (Kuuluvainen 2009). It is evident that the current retention practice in Fennoscandia cannot be regarded as an alternative to clearcutting, but rather as one form of it.

There may also be knowledge "lock-ins" (Puettmann et al. 2008; Moen et al. 2014). Much is dependent on how forest managers and policymakers understand retention's purposes and ecological functions. In their mindset, low retention can be regarded as an externally easy solution to the problems of the traditional clearcutting system. The widespread adoption of retention forestry probably came about at least partly because it does not require changing the underlying business-as-usual management, i.e., clearcutting based on even-aged management and associated forestry logistics. Easy implementation is tempting, but the ecological insight may be lacking and the problems related to clearcutting mostly remain despite financial sacrifice (Kuuluvainen 2009).

A major ecological problem is that few individual retention trees, or small routinely left retention groups of 5-10 small-sized trees (Fig. 1), simply do not provide the habitat quality and continuity needed by various species groups (e.g., red-listed epiphytes and saproxylics, see Jääskeläinen et al. 2010; Siitonen 2012). Thus, a critical
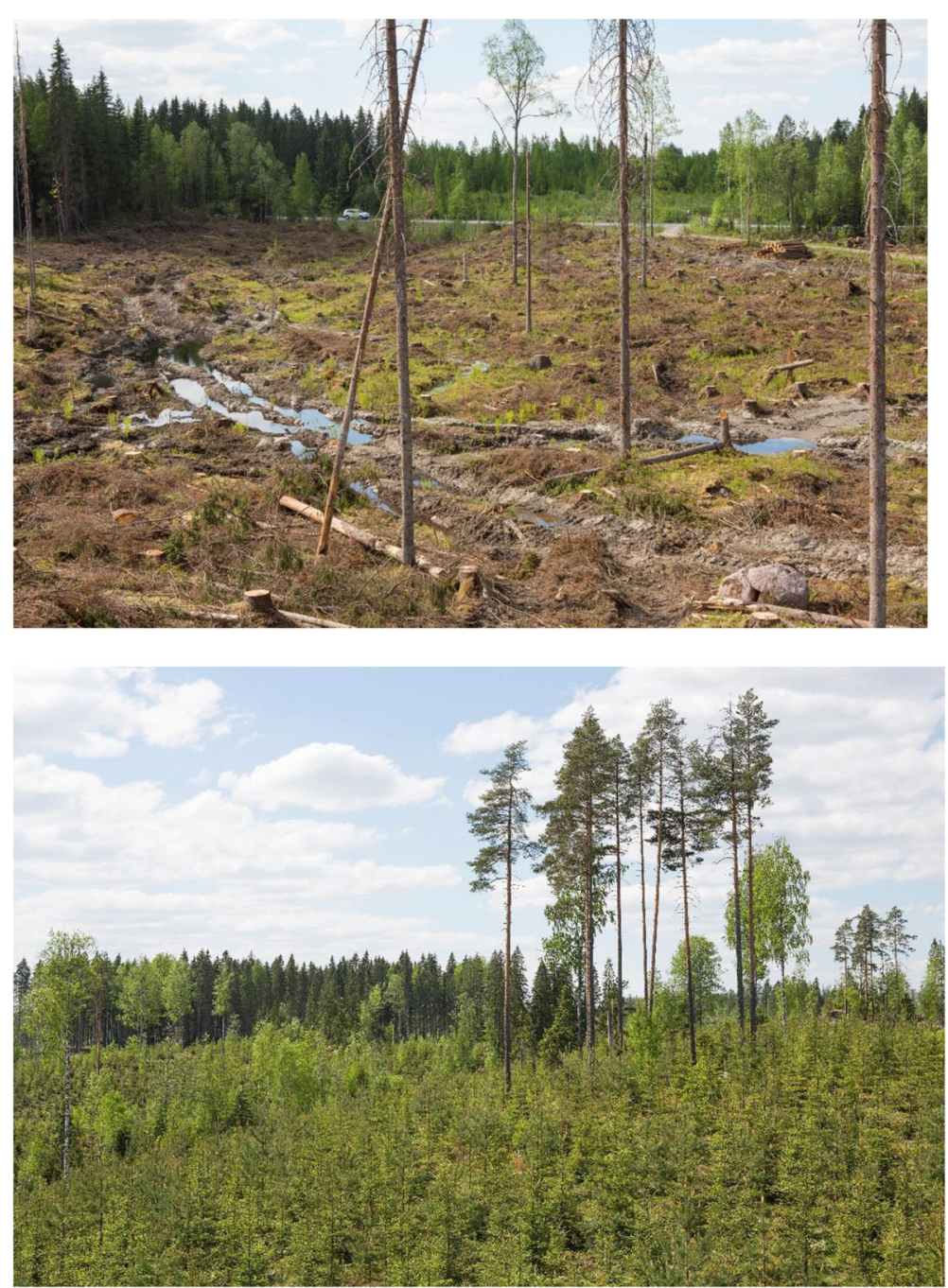

Fig. 1 Above: a typical small fresh clearcut with some retention trees in Finland after harvesting. Below: a regenerated clearcut with retentiontree groups in Finland. Photos: Erkki Oksanen/Luke 
issue for the success of the retention approach is how much and what kind of retention is needed and should be left in the spatial stand mosaic created by clearcut harvesting.

However, the focus of leaving retention trees is usually on a stand (compartment) scale (alpha diversity), while intralandscape variability (beta diversity) receives little attention in guidelines and practice. Finland is an example of a case in which the standscale focus may be the result from a political decision with the purpose of treating forest owners equally, since no compensation is paid for leaving more than the required amount of retention. However, it is evident from ecological theory that variation in habitat characteristics resulting from forest dynamics is essential for biodiversity (Kuuluvainen 2002). Mimicking natural forest habitats could mean leaving higher amounts of retention in some stands to create concentrations of more diverse deadwood habitats in the long run. In short, the common restricted stand-scale focusing hampers efficient ecological multiscale applications of the retention approach (Lindenmayer and Franklin 2002). From the ecological point of view, the challenges of retention systems reflect the fact that ecological knowledge of natural disturbances, forest structures, and disturbance legacies and their dynamics are only loosely, or not at all, integrated into current retention-management schemes (Kuuluvainen 2009).

We examine these challenges in retention practice and take Finland as a case study. Finland is a wealthy developed country with a long history of intensive forest utilization (Keto-Tokoi and Kuuluvainen 2014). Private forest ownership is high (61\% of forest land area; Peltola 2014). The knowledge level of how to manage forests for timber production is high and likewise is the knowledge of forest ecology, at least as compared with many other boreal regions (Kuuluvainen and Siitonen 2013). The forest industry and its exports have been and still are central parts of the national economy in Finland. Therefore, the retention approach as a component of forest certification has been and continues to be crucially important in forest policy to allow access of forestry and wood products to the market.

\section{A case study: retention-tree practice in Finland Development}

In Finland, the first retention trees were left during final harvesting in the late 1980s when individual large European aspen (Populus tremula L.) trees were left in clearcut areas (Simonsson et al. 2015). Prior to that, all trees were more or less removed from the harvesting area in clear fellings since the 1950s. A more extensive retention practice was initiated in the mid-1990s in the aftermath of the Rio Convention of Biological Diversity, when forest organizations were forced to respond to the growing criticism against intensive forestry practices.

The criticism from citizens and environmental protection organizations could have been tolerated by forestry organizations as before, but the crucial turning point was the increasing awareness of consumers and customers of exported paper products concerning the environmental impacts of intensive forestry practices. Both in Finland and Sweden, the paper industry sector in particular was suddenly confronted with the fact that there could be significant difficulties in the marketing of their products, unless forest management practices were made more environmentally friendly (Simonsson et al. 2015).

In Finland, two influential publications steered forest management policies toward retention forestry. The New Environmental Programme for Forestry (NEPFF) was published by the Ministry of Agriculture and Forestry and the Ministry of the Environment (1994). This strategy report did not specifically recommend retention forestry, but it set a demand to modify Finnish forest management to become more environmentally friendly. A parallel development was ongoing in Sweden (Swedish Forestry Act of 1993).

The strategy outlined in NEPFF was complemented with forest management guidelines for private forests published by the Forestry Centre Tapio (Metsäkeskus Tapio 1994). These influential guidelines consisted of recommended management practices that were then put into practice by the Forest Owners' Association (FOA). These were responsible for forest management in private forests and were controlled by forest authorities. In the Tapio guidelines for close-to-nature silviculture (Metsäkeskus Tapio 1994), the instructions were shifted to recommendations, thus reducing strict regulation. They were the first forest management guidelines in which environmental aspects and methods were introduced on a wide scale. In this context, leaving retention trees was aimed at mitigating the negative ecological and esthetic effects of clearcutting forestry. The retention practice was also a response to the public opinion criticizing clearcuttings' negative impacts on scenic values and recreational use (Gundersen and Frivold 2008; Simonsson et al. 2015).

This situation also inspired research and led to some stand-level experiments on the effects of various forest management practices, including retention, on biodiversity, both in Sweden (Sustainable Forestry in Southern Sweden SUFOR, Sverdrup and Stjernquist 2002) and in Finland (Biodiversity and regeneration of Norway spruce forests, MONTA, Vanha-Majamaa and Jalonen 2001). However, these experiments were not solely focused on retention forestry by definition, since SUFOR more widely addressed sustainability issues, and in MONTA 
only one of the treatments was true permanent retention (Vanha-Majamaa et al. 2017).

Due to the multiple pressures on clearcutting forestry, the retention method was rapidly taken into practice, but with only minor scientific evidence of the functionality of the method in Finland. Retention practice was thus introduced and applied as some kind of "cure-all" in a situation where something had to be done in response to the increasing environmental criticism. Finland quickly adapted policies similar to those Sweden had introduced some years earlier (Simonsson et al. 2015). In both cases, it was foremost a reaction intended to show the buyers of forest industry products that biodiversity and ecological sustainability were taken into account in Finnish forestry.

The retention practice was based on recommendations introduced in the 1994 forest management guidelines for private forests (Metsäkeskus Tapio 1994). The use of green-tree retention was formalized when forest certification was launched in 1998-1999 with a national standard (Metsäsertifioinnin valmiusprojekti 1998). In 2000 , the national standard was accepted for incorporation into the PEFC system (since 2003 the Programme for the Endorsement of Forest Certification). The standard (SMS, Metsäsertifioinnin valmiusprojekti 1998) included a special criterion (\#21) that required leaving a minimum of five retention trees per hectare in cutting operations, and the criterion emphasized large-sized and old trees without setting diameter requirements. The criterion also listed a variety of dead trees that should be retained if such trees existed in the area. The standard was later revised every 5 years in 2004-2005 as the Finnish Forest Certification System (FFCS, Metsäsertifioinnin standardityöryhmä 2003) and in 2009 (PEFC Finland 2009) and 2014 as PEFC (PEFC Finland 2014).

The certification was implemented as group certification that in 2016 covered more than $90 \%$ of Finland's managed forests. High coverage was essentially based on mandatory membership of forest owners in the FOAs. When the obligatory membership fee was removed in 2014, due to changes in legislation, the system was renewed. Private forest owners are still mostly groupcertified, either by FOA membership or by individual membership. Some large forest organizations such as the State-owned forestry company Metsähallitus Forestry Ltd. and large private forest companies currently have their own PEFC certificates. Currently, PEFC certification covers approximately 18 million hectares (92\%) of the managed forests in Finland (PEFC Finland 2019).

During the 20 years of existence of PEFC forest certification in Finland, the criteria dealing with retention have remained by and large the same. Yet, the indicator levels (thresholds) that actually specify the on-the-ground requirements have been significantly weakened (Table 1).

Table 1 Contents of retention-tree criteria of the national Finnish forest certification standards PEFC and FSC during 1998-2014. Minimum number: minimum number of required retention trees/hectare; Minimum size: minimum DBH (cm) required for retention trees. Substitution with dead trees: are dead trees accepted as substitutes for living retention trees or not. References: $1=$ Metsäsertifioinnin valmiusprojekti 1998, 2 = Metsäsertifioinnin standardityöryhmä 2003, 3 = PEFC Finland 2009, 4 = PEFC Finland 2014, 5 = The Board of the Finnish FSC Association 2005, 6 = Finnish FSC Association 2010)

\begin{tabular}{|c|c|c|c|c|c|}
\hline Standard & Criterion & Minimum number & Minimum size & Substitution with dead trees & Reference \\
\hline SMS/PEFC & $\begin{array}{l}\text { \#21: "Retention trees shall be left in } \\
\text { regeneration areas" }\end{array}$ & 5 & $\begin{array}{l}\text { Not defined, but wording } \\
\text { indicates coarseness }\end{array}$ & $\begin{array}{l}\text { No, but it is recommended } \\
\text { that dead trees should be } \\
\text { retained }\end{array}$ & 1 \\
\hline FFCS/PEFC & $\begin{array}{l}\text { \#12: "Retention trees shall be left in } \\
\text { regeneration areas" }\end{array}$ & $5(5-10)$ & $\geq 10 \mathrm{~cm}$ & Yes, $\mathrm{DBH} \geq 10 \mathrm{~cm}$ & 2 \\
\hline PEFC & $\begin{array}{l}\text { \#13: "Retention trees and decaying } \\
\text { wood shall be left in forestry } \\
\text { operations" }\end{array}$ & $5(5-10)$ & $>10 \mathrm{~cm}$ & Yes, DBH $>20 \mathrm{~cm}$ & 3 \\
\hline PEFC & $\begin{array}{l}\text { \#14: "Retention trees and decaying } \\
\text { tree stems shall be left on site in } \\
\text { forestry operations" }\end{array}$ & 10 & $>10 \mathrm{~cm}$ & Yes, DBH $>20 \mathrm{~cm}$ & 4 \\
\hline FSC & $\begin{array}{l}\text { \#6.3.2: "Retention trees shall be } \\
\text { preserved in each harvesting } \\
\text { operation" }\end{array}$ & 10 & $\geq 20 \mathrm{~cm}$ & $\begin{array}{l}\text { No, dead trees must be } \\
\text { retained or established } \\
\text { according to another } \\
\text { criterion (6.3.1) }\end{array}$ & 5 \\
\hline FSC & $\begin{array}{l}\text { \#6.3.2: "On a regeneration felling } \\
\text { compartment, } \\
\text { the forest owner shall permanently } \\
\text { retain: minimum average of } 10 \\
\text { large-diameter ... living trees of } \\
\text { native species per hectare." }\end{array}$ & 10 & $\begin{array}{l}>20 \mathrm{~cm} \text { in Southern } \\
\text { Finland, }>15 \mathrm{~cm} \text { in } \\
\text { Northern Finland }\end{array}$ & $\begin{array}{l}\text { No, dead trees must be retained } \\
\text { according to another criterion } \\
\text { (6.3.1) }\end{array}$ & 6 \\
\hline
\end{tabular}


The most important changes occurred in 2004 when the minimum diameter requirement of retention trees was set to a diameter at breast height $(\mathrm{DBH})$ of $10 \mathrm{~cm}$, instead of earlier emphasis on coarseness of retained trees. In addition, dead trees were accepted as retention trees compared with the previous practice only accepting green-tree retention (Table 1 ). This naturally meant a drop in retention volumes. Only in the latest update of the PEFC standard was a slight improvement achieved when the minimum number of retention trees was increased from 5 to 10 trees per hectare, although the minimum diameter remained small $(\mathrm{DBH} 10 \mathrm{~cm})$ and dead trees remained as possible substitutes for living retention trees (PEFC Finland 2014).

FSC certification was initiated on a wider scale in Finland only in the 2010s (2011 onwards) when large forest companies began certifying their forests according to the FSC standard (Finnish FSC Association 2010), but a small area of app. 10,000 ha had already been certified according to the first version of the FSC standard (The Board of the Finnish FSC Association 2005). FSC certification has so far mainly been promoted by large forest companies, but gradually the number of private forest owners is also increasing. Currently, FSC-certified forests cover 1.8 million ha (10\%) of Finland's managed forest land area (FSC Suomi 2018). Most landowners that have adopted the FSC certification are also in the PEFC system. Currently, FSC requires at least 10 retention trees, with $>20$ $\mathrm{cm} \mathrm{DBH}$ in southern and $>15 \mathrm{~cm} \mathrm{DBH}$ in northern Finland, while dead trees must be retained according to their own individual criteria and, thus, they cannot substitute for living retention trees (Table 1).

Both of the forest certification standards applied in Finland, PEFC and FSC, state that the retention trees are left permanently in the clearcut areas. In the Finnish monitoring scheme for retention forestry of private forests, the clearcut areas are monitored, based on a random sample of cutting areas soon after regeneration cuttings. However, these data may not reveal the later removals of retention trees by the forest owners, e.g., for household uses. In inventories performed later after clearcutting, removal of retention trees was observed in almost every third of the cutting areas inspected, and harvesting was focused on large-diameter retention trees (Salomäki 2005; Kurttila and Hänninen 2006; Hänninen et al. 2008, 2010). Furthermore, it was not indicated whether the same trees could be counted as new retention trees in the next rotation cycle or not in either of the standards. From the ecological point of view, however, each rotation cycle should yield a new set of retention trees to ensure the continuity of old living trees and CWD, which is the basic idea of retention (Kotiaho et al. 2006).

The forest certification systems set the minimum requirements for landowners committed to certification.
Yet, the guidelines and practices vary significantly from case to case. Public landowners and large forest companies generally have more ambitious management goals and guidelines for green-tree retention than those required by PEFC certification criteria. For example, Metsähallitus Forestry Ltd. (manager of the State commercial forests) sets a target of 10 coarse $(\mathrm{DBH} \geq 20 \mathrm{~cm}$ in the south or $\geq$ $15 \mathrm{~cm}$ in the north) living retention trees per hectare as well as preservation of all dead trees (such that are not likely to increase bark beetle outbreak risk) in their recently revised guidelines (Kaukonen et al. 2018).

\section{Retention-tree volumes}

The systematic annual monitoring of the quality of environmental management in cutting operations in Finland was initiated in private forests by Forestry Centre Tapio in 1995 and is continued by the Finnish Forest Centre, while comparable data for retention levels are available from 1998 onwards. In the monitoring, a random sample of all cutting areas is annually selected and monitored, using standardized methods. These data were earlier published on a national level in the internet service "Metsä vastaa" (http://www.metsavastaa.net/) which was maintained by Forestry Centre Tapio till 2014, and later data are available in the internet service maintained by Finnish Forest Centre (Finnish Forest Centre 2019). We use these data in the analyses below. We calculated Kendall's rank correlation coefficients (Kendall's tau) to tests changes in the retention-variable levels among the monitoring years using the package Kendall (McLeod 2011) in R version 3.5.1 (R Core Team 2018).

The measurements include the number and volume of retention trees by tree species and size class and the level of retention (proportions of stand volume harvested, retained as living retention trees, and trees left in set-asides) (Fig. 2, 3, and 4). We use monitoring data of 1998-2017 for all the other analyses except for the level of retention for which we omitted the last monitoring year 2017 because of methodological changes in how these data were obtained by Finnish Forest Centre.

The average retention level (proportion of living retention trees) was $1.8 \%$ during the first 5 -year certification period of PEFC certification (2000-2004), but it has declined so that an average of $1.2 \%$ of stand volume was retained in living retention trees in the 5-year period 2013-2017 (Fig. 2). The total volume of living retention trees was on average $3.2 \mathrm{~m}^{3} /$ ha and $2.7 \mathrm{~m}^{3} /$ ha in 2000 2004 and 2013-2017, respectively (Fig. 3). The reduction in retention levels evidently was because large living retention trees $(\mathrm{DBH}>20 \mathrm{~cm})$ were partly replaced with small-diameter trees (DBH $10-20 \mathrm{~cm}$ ) and dead trees (Fig. 4) following the ecological impairments in the PEFC standard in force from 2005 onwards. It is too early to say if the latest change in the retention-tree 


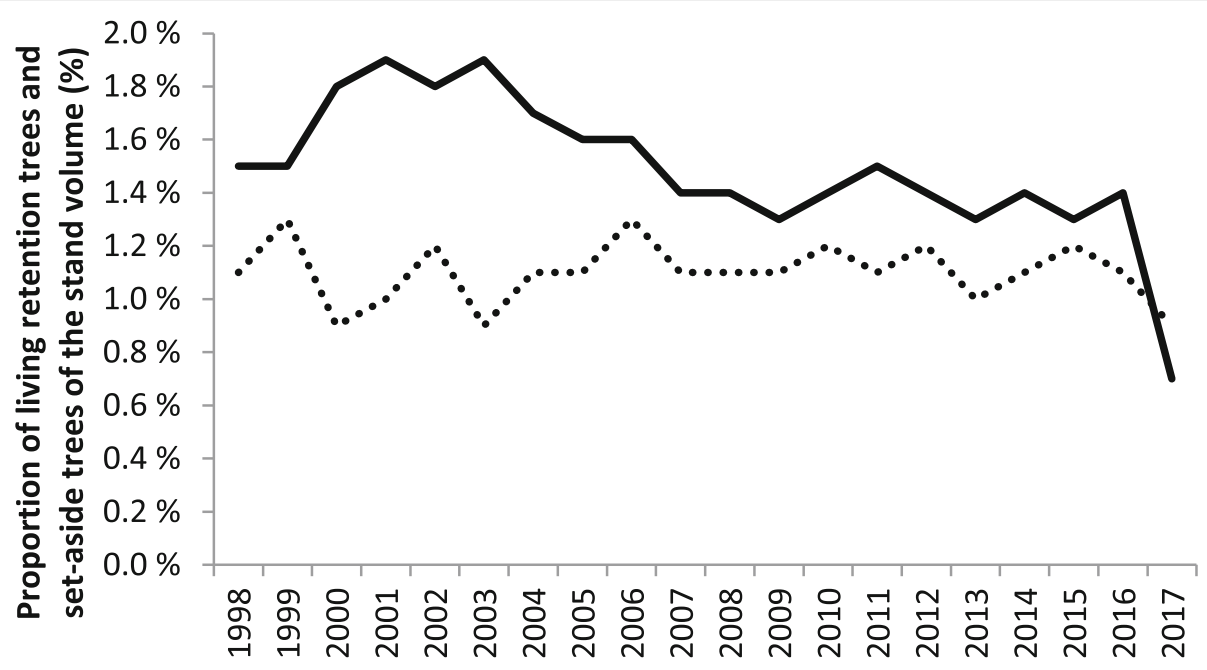

\section{Monitoring year}

Fig. 2 Proportion of living retention trees (solid line) and living trees retained in set-asides (different types of valuable woodland key habitats, dotted line) of the stand volume (\%) in 1998-2017 in clearcutting areas of private forests (data: Forestry Centre Tapio 2013, Finnish Forest Centre 2019). The proportion of living retention trees of the stand volume has decreased during the monitoring years from the level of the early years of PEFC certification (early 2000s) (Kendall's rank correlation coefficient $r_{K}=-0.57, p=0.001$ ) whereas the proportion of living trees retained in setasides has remained the same $\left(r_{k}=0.11, p=0.574\right)$. Thus, also the pooled proportion of living retention trees and living trees retained in setasides of the stand volume has decreased $\left(r_{K}=-0.50, p=0.005\right)$. Data for the year 2017 were not included in the above analyses (see text)

criterion in the PEFC, an increase in the minimum number of trees per hectare from 5 to 10 trees (PEFC Finland 2014) has had any notable effect on the retention level because the revised standard has been operative only from 2016 onwards: the retention volumes may have slightly decreased (Fig. 3) and the numbers of retention trees may have slightly increased (Fig. 4).

Forest management guidelines have recommended that the retention trees should be concentrated in retentiontree groups and, when possible, in the immediate vicinity

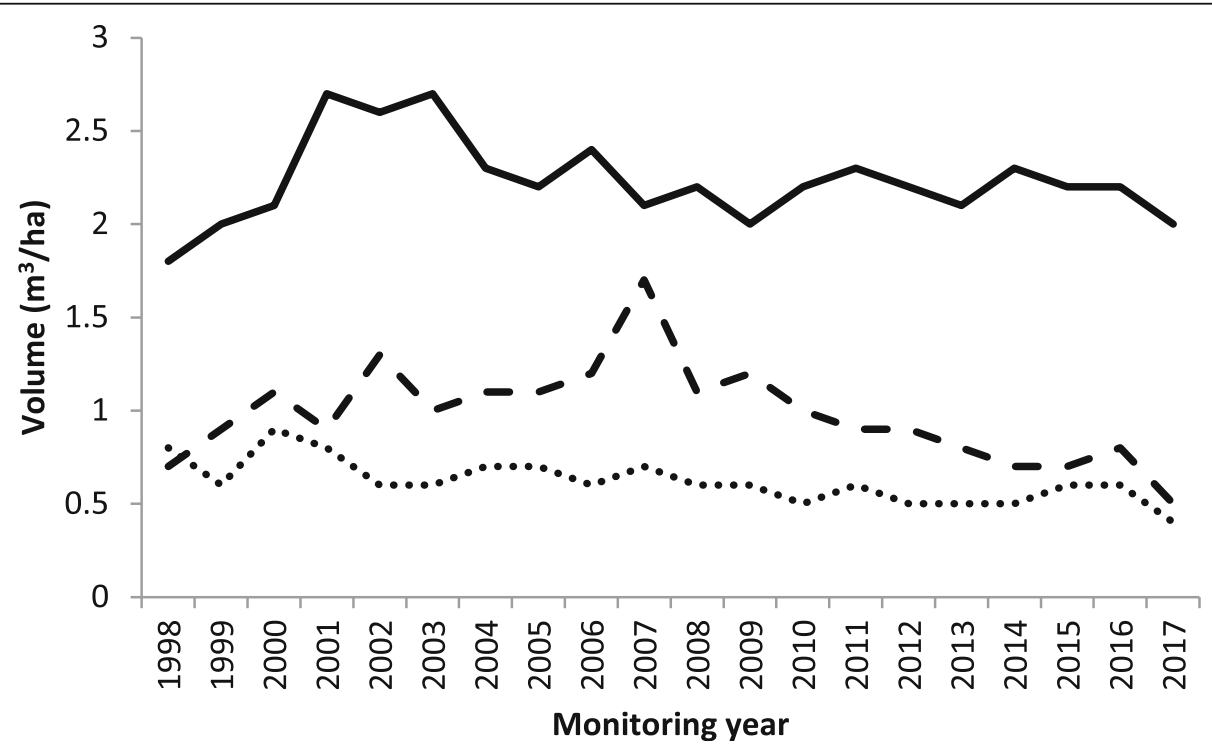

Fig. 3 Volumes of living large-diameter ( $\mathrm{DBH}>20 \mathrm{~cm}$, solid line) and small-diameter (10-20 cm, dotted lined) retention trees and dead trees (DBH > $10 \mathrm{~cm}$ or DBH $>20 \mathrm{~cm}$ from 2005 onwards, dashed line) (m³/ha) in 1998-2017 in clearcutting areas of private forests (data: Forestry Centre Tapio 2013, Finnish Forest Centre 2019). The volume of living large-diameter retention trees has remained quite the same despite the starting peak in the early years of PEFC certification (early 2000s) (Kendall's rank correlation coefficient $r_{K}=-0.08, p=0.643$ ). The volume of living small-diameter retention trees has decreased during the monitoring years $\left(r_{K}=-0.61, p<0.001\right)$ and that of dead retention trees has slightly decreased but not statistically significantly so $\left(r_{K}=-0.33, p=0.053\right)$. The pooled volume of all living retention trees has decreased $\left(r_{K}=-0.35, p=0.041\right)$ 


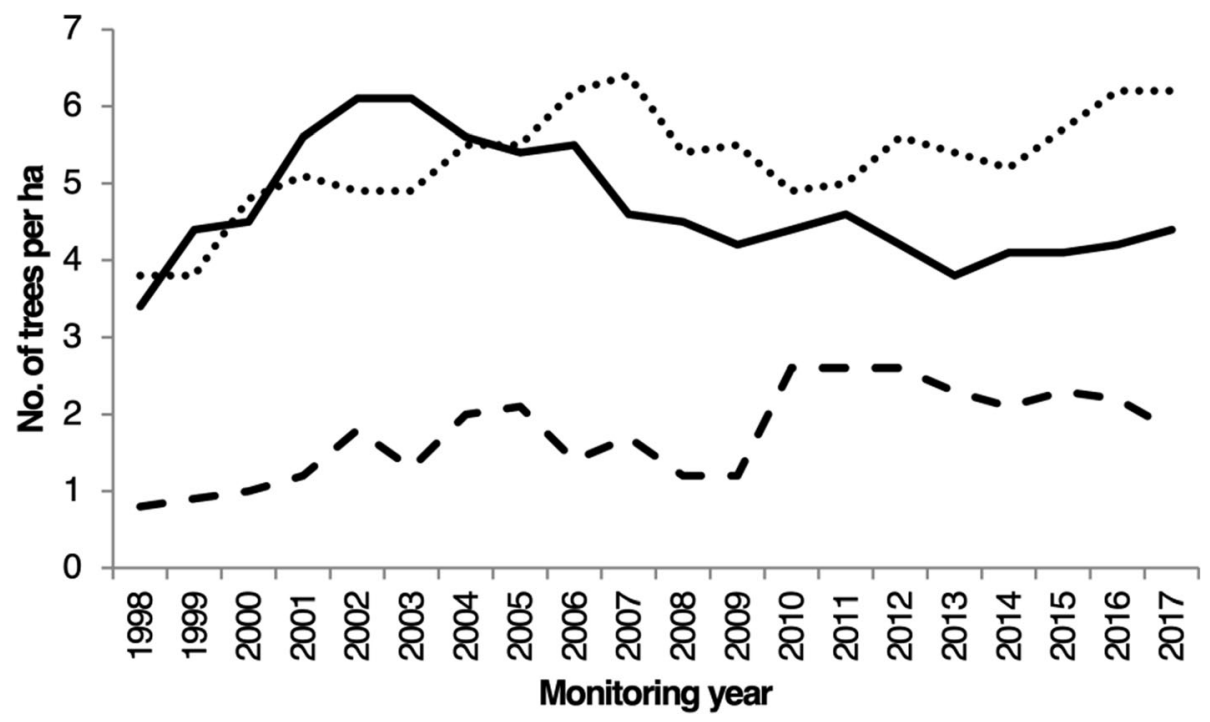

Fig. 4 Numbers of living large-diameter (DBH $>20 \mathrm{~cm}$, solid line) and small-diameter (10-20 cm, dotted line) retention trees and dead trees (DBH $>10 \mathrm{~cm}$ or DBH > $20 \mathrm{~cm}$ from 2005 onwards, dashed line) (no. of trees per hectare) in 1998-2017 in clearcutting areas of private forests (data: Forestry Centre Tapio 2013, Finnish Forest Centre 2019). The numbers of living large-diameter retention trees have decreased during the monitoring years from the level of the early years of PEFC certification (early 2000s) (Kendall's rank correlation coefficient $r_{K}=-0.37, p=0.026$ ), and the numbers of living small-diameter retention trees $\left(r_{K}=0.52, p=0.002\right)$ and dead retention trees $\left(r_{k}=0.51, p=0.002\right)$ have increased during the monitoring years. The pooled numbers of all living retention trees $\left(r_{k}=-0.01, p=1.0\right)$ have remained the same during the monitoring years

of set-asides, i.e., different types of valuable woodland key habitats. Thus, one might think that the reduced retention level for living retention trees may have been compensated for by increasing the numbers of living trees in set-asides and their proximity. This, however, seems not to be the case, since the proportion of stand volume retained in setasides has remained largely the same (Fig. 2).

According to the Finnish National Forest Inventories (NFIs) performed by the Natural Resources Institute Finland, the practice of retention increased the volume of living tree stock in the temporarily unstocked young regeneration stands from less than $3 \mathrm{~m}^{3} /$ ha prior to the beginning of the forest certification era (data from NFI8, 1986-1994, Tomppo et al. 2001) to $8 \mathrm{~m}^{3} / \mathrm{ha}$ (NFI9, 1996-2003) to and $9 \mathrm{~m}^{3} / \mathrm{ha}$ (NFI10, 2004-2008). However, in later inventories, it decreased to $7 \mathrm{~m}^{3} / \mathrm{ha}$ (NFI11, 2009-2013) (data from Peltola 2014). In addition to private forests, these data also include state and forest company forests with typically higher retention levels. Furthermore, these NFI data also include, in addition to actual retention trees, such seed trees and shelter trees that have not been harvested in due course after regeneration cuttings.

\section{Effects on biodiversity}

In Finland, species responses to retention have been studied, mainly based on larger experimental setups with different levels of retention (Vanha-Majamaa and Jalonen 2001; Hyvärinen et al. 2005; Heikkala et al. 2014;
Johnson et al. 2014; Vanha-Majamaa et al. 2017; Granath et al. 2018), which are complemented by some individual field studies (Kaila et al. 1997; Martikainen 2001; Junninen et al. 2007; Oldén et al. 2014). Most studies share the result that retention may positively affect some species groups, but the response is dependent on the level of retention and species in question (Johnson et al. 2014; Vanha-Majamaa et al. 2017).

The benefits of current retention levels on saproxylic beetles (Coleoptera) appear to be relatively small (Heikkala et al. 2016). However, even low levels of retention can benefit some specialized species, such as aspendependent beetles (Martikainen 2001) and polypores (Junninen et al. 2007). Retention trees' long-term effects must also be considered. Even rather low levels of retention, 10 trees per hectare, will increase the structural variability of future stands, as shown by Kruys et al. (2013) covering a time period of 25 years. In the long run, changes in forest structures can provide habitat for many species groups (see also Henttonen et al. 2019 for old and large trees).

For preserving preharvest late-successional plant communities in cuttings, the current retention levels in Finnish forestry are clearly too low. In fact, even retention volumes as much as 10 times higher do not ensure the "lifeboating" of precutting plant communities in mature forests (Vanha-Majamaa et al. 2017). For example, in their experiment, Vanha-Majamaa et al. (2017) found no remarkable differences in effects on understory 
vegetation between clear felling and felling with 7\% retention (on average 51 trees per hectare) during a 10year period after harvesting. Results from both North America and Fennoscandia have shown that even 15$17 \%$ retention is insufficient to retain the abundance and diversity of understory plant species characteristic of late-successional stages and that the changes in understory vegetation due to harvesting are reduced only at higher levels of retention (Craig and Macdonald 2009; Halpern et al. 2012; Johnson et al. 2014). This is clearly due to the fact that the microclimate within small retention patches resembles that in clearcuts (Chen et al. 1995; Heithecker and Halpern 2007).

\section{Fire and retention}

In Finland, two large research experiments involving a retention treatment also included a prescribed burning treatment (Hyvärinen et al. 2005; Vanha-Majamaa et al. 2007). Studies based on these experiments focusing on saproxylic beetles (Hyvärinen et al. 2006; Heikkala et al. 2016), flat bugs (Heikkala et al. 2017), and polypores (Berglund et al. 2011; Suominen et al. 2015) showed a positive effect of burning. Thus, prescribed burning together with the leaving of retention trees has been strongly recommended as an efficient restoration and environmental management tool, and leaving higher than normal retention levels on burned sites has been advocated in these studies. At low levels of retention, however, fire-induced tree mortality results in a transitory pulse in CWD input and interrupts the continuity of living trees. Therefore, higher retention levels of 10$20 \%$ have been recommended to secure longer-term availability of CWD and living retention trees in prescribed burning (Heikkala et al. 2014).

Unfortunately, despite all recommendations, forest certification criteria, and development projects (the latest being the large evaluations of Matveinen et al. 2015; Kouki et al. 2018; Hyvärinen et al. 2019), the areas treated by prescribed burning have steadily decreased in Finland and currently have sunk below 500 ha per year (Peltola 2014), while the average for 2015-2017 was only 196 ha according to the statistics database of Natural Resources Institute Finland (2019).

\section{Evaluation of Finnish retention practice}

Examining the development of the retention-tree criteria and indicators of the Finnish PEFC certification system reveals two major ecological impairments that have occurred. Firstly, coarse-diameter living retention trees were partly replaced with smaller trees $(>10 \mathrm{~cm} \mathrm{DBH}$, Table 1). This meant a dramatic drop in the minimum retention volume because, for example, the volume of a $10 \mathrm{~cm} \mathrm{DBH}$ tree is only $15-17 \%$ of that of a $20 \mathrm{~cm} \mathrm{DBH}$ tree, depending on the species (calculated using volume equations based on DBH, Laasasenaho 1982). Secondly, for dead trees, there is now no criterion of their own, but instead they are counted in the criterion for living retention trees, in which they can be used to substitute for living retention trees. These major impairments were already carried out in the first update of the PEFC standard.

These impairments in retention practice were accompanied by weakening of two other ecological criteria and indicators, which are not directly related to retention on clearcuts but affect the amount of trees retained in the landscape. Firstly, the numbers of valuable woodland key habitats (other than those already safeguarded by Forest Act and Nature Conservation Act) were reduced and their definitions modified, resulting in a $95 \%$ reduction in their area safeguarded by the PEFC certification (Kuusinen 2006; Nieminen 2006a, 2006b). Secondly, the criterion concerning prescribed burning (and the use of fire generally to aid biodiversity) was weakened. The original ambitious goal to "double the area burned" during the first 5-year period of the certification (see Table 1) was strongly cut down already in the first update of the PEFC standard by setting the target to "keep the area burned at the same level" and by accepting all the accidental forest fires and the burning of occasional small retention-tree groups and even restoration fires in conservation areas as substitutes for the prescribed burnings of managed forests. In the second update of the PEFC standard, the ecological impairments were continued further by making it possible to substitute surface area (hectares) burned with counts of sites burned independently from their surface area. Finally, in the latest update of the PEFC standard, only the numbers of burnings regardless their surface sizes were counted.

The accumulated research evidence clearly shows that the current retention levels in the Finnish PEFC certification scheme are far too low for significant positive biodiversity impact. Despite this, the ecological criteria of the certification system have been impaired. It seems that the policy goal has been to search for the lowest possible retention level and maintain a status quo, rather than to develop the retention approach to deliver tangible ecological benefits as advised by current scientific understanding.

\section{Discussion}

In Finland and also elsewhere in Fennoscandia, retention practice was quickly implemented with a low level of retention in the 1990s (Simonsson et al. 2015). The main driver was the fact that something had to be done to maintain access to the market and to improve the tainted image of forestry and the forest industry. However, there was no interest in changing the business-asusual management system: even-aged management 
based on clearcut harvesting. Since relevant research concerning the ecological impacts of retention was largely lacking, it was hoped that the low-retention approach selected would work somehow in most situations. Thus, low retention was used as a "band-aid" or "cure-all" solution. It is apparent that the low level of retention chosen was some kind of compromise between wishful thinking concerning ecological benefits and the desire to minimize economic costs. The economic benefits of low retention practice are evident: small economic losses from reduced harvesting volumes, low competition effect on new tree generation, and low impact on harvesting and regeneration costs. Above all, the widescale implementation of the retention approach was intended to give forestry a more environmentally friendly image.

The ecological functionality of the retention approach is emphasized in areas where forest management is intensive and coverage of conservation areas is small. An example is provided by Southern Finland, where less than 3\% of forest land area is conservation areas or otherwise not available for wood production and the remaining $97 \%$ of forest land is available for wood production (Korhonen et al. 2017). The disappearance of natural forest habitats and forest management has been considered to be responsible for the decline in a large number of threatened species (31\% of all threatened species live primarily in forests) (Hyvärinen et al. 2019). Hence, the activities carried out, especially in final fellings, are of major importance in maintaining biodiversity. The existing ecological evidence suggests that much higher retention levels than currently applied in Finland would be needed for obtaining tangible ecological benefits, such as a halt in the decline of many rare and redlisted species depending on large and old living trees and CWD.

Various studies have documented a positive correlation between the amount of retention and biodiversity (Rosenwald and Lõhmus 2008; Gustafsson et al. 2010; Fedrowitz et al. 2014), thus emphasizing the crucial role of retention level. However, in some cases, even lower retention levels can be favorable if they provide some key resources that have decreased due to intensive forest management. Thus, even individual coarse trees, such as aspens Populus L. and birches Betula L., and probably also other key tree species, may be important (Kaila et al. 1997; Martikainen 2001; Junninen et al. 2007). And in the long run, retention trees will eventually increase the numbers of old trees in managed forests (Henttonen et al. 2019), given that they are not harvested later on (see Salomäki 2005; Kurttila and Hänninen 2006; Hänninen et al. 2008, 2010).

As shown by case Finland, retention practice as a component of a certification scheme appears foremost as a forest policy and marketing instrument. Policymakers and managers may view retention trees as an external "cost" to traditional roundwood-oriented management practice rather than an approach for managing the ecosystem for multiple goals and services. Then the aim may not be to attain specific ecological goals, but to manage with the lowest possible retention that still safeguards the access of forestry products to the market. This occurs when goals and threshold values for key ecological variables, such as CWD, are lower than required by many rare and red-listed saproxylic species (e.g., Hyvärinen et al. 2019). Not surprisingly, most problems related to retention are direct consequences of the low levels of retention. The Finnish PEFC certification with very low retention requirements is an example of such a case, in which sound ecological applications may be totally compromised by the requirements for efficient timber production.

There are several ways in which retention practice can be developed to attain the ecological effects desired. Perhaps the most important decision is to define an effective retention level. Recent expert opinion suggests that the strict minimum retention level is $5-10 \%$ of standing stock, and considerably more in many cases (Gustafsson et al. 2012). Choosing suitable retention trees at stand scale should already be done in early stand development stages. Such trees may be of specific species, of low timber quality, have different kinds of damage, old and/or large-diameter trees, features that are known to enhance habitat heterogeneity. Before final harvesting, retentiontree groups should be marked so that their understory is not cleaned, as is customary. It is also important to leave more retention trees around protection areas and valuable habitats.

Small-scale site-type variation can be utilized when locating retention-tree groups. For example, in Norway spruce (Picea abies (L.) Karst.) stands, more retention could be saved in paludified patches with rich flora and often higher amounts of CWD in comparison to the surrounding areas (Vanha-Majamaa and Jalonen 2001). This would create concentrations of CWD, which probably would be beneficial for maintenance of species diversity. Similarly, in Scots pine (Pinus sylvestris L.) stands the retention-tree groups should be planned at sites likely to be left unburned in forest fires, thus mimicking natural disturbance pattern (Wallenius et al. 2004).

In addition to leaving live retention trees, avoiding the unintentional destruction of CWD, and avoiding the harvesting of CWD for energy wood in all harvesting operations (Forsius et al. 2016; Korhonen et al. 2016) would rapidly yield increased levels of deadwood, compared with the current situation with low deadwood levels in managed forests. The volumes 
of large-diameter dead trees extracted for energy wood or unintentionally destroyed in management operations currently surpass the annual retention volumes of living retention trees in private forests (Forsius et al. 2016; Korhonen et al. 2016).

Landscape-level planning should also better utilize knowledge of forest disturbance ecology and site-type heterogeneity. Ecological theory explains that biodiversity is dependent on multiscale variability of forest habitat structures driven by disturbances. However, it is a common practice in Finland that the same low number of retention trees is routinely left in each clearcut to lower economic costs and to treat forest owners equally when it comes down to private forests. This practice leads to ecologically inefficient use of minimum retention levels spread thinly and monotonously across the landscape. In ecological terms, the focus is on stand-scale forest structure and composition (alpha diversity) rather than intralandscape variability (beta diversity) in retention structures. The result is decline in stand- and landscape-scale habitat variability. Although it is stated in the retention literature that the approach is based on lessons and knowledge from natural disturbances (Gustafsson et al. 2010, 2012), the use and implementation of this knowledge in on-the-ground management remain highly elusive.

\section{Conclusions}

The ecological aim of leaving retention trees in managed forests is to safeguard some of the key structural, functional, and compositional diversity characteristics of natural forest ecosystems. However, as shown by the Finnish case, the retention approach can fail to provide tangible ecological improvements because of a lack of policy ambition and/or ignoring of current scientific understanding of the ecological responses to retention practice. These problems reflect how the retention approach is motivated, defined, and implemented, whether it is mainly seen as a marketing instrument, or if there is a genuine interest in attaining specific ecological goals, such as effectively safeguarding biodiversity.

Our case study of Finland shows that the practice of retention currently lacks ecological credibility, and it should urgently be developed to more efficiently safeguard biodiversity. To attain tangible ecological effects, the most important decision is to define an effective retention level, which according to current expert opinion is a minimum of $5-10 \%$ of standing stock, and more in many situations (Gustafsson et al. 2012). In addition, the retention practices should be developed, using up-todate ecological knowledge concerning species' habitat requirements, forest disturbance ecology, and legacy structures at multiple scales.

\section{Abbreviations}

CWD: Coarse woody debris; DBH: Diameter at breast height; FFCS: Finnish Forest Certification System; FOA: Forest Owners' Association in Finland; FSC: Forest Stewardship Council; MONTA: Biodiversity and regeneration of Norway spruce forest; NEPFF: New Environmental Programme for Forestry in Finland; PEFC: Programme for the Endorsement of Forest Certification;

SUFOR: Sustainable Forestry in Southern Sweden project (1996-2004)

\section{Acknowledgements}

We thank an anonymous referee and Håkan Berglund for useful comments on the manuscript.

\section{Consent of publication}

Not applicable

\section{Authors' contributions}

TK presented the idea and compiled the final version of the manuscript. PP, $\mathrm{HL}, \mathrm{IVM}$, and PK participated in writing and commented on the manuscript. All authors read and approved the final manuscript.

\section{Funding}

No specific funding was used as all authors worked to produce this paper as part of their normal working duties.

Availability of data and materials

Because this was a review, no new data were generated.

Ethics approval and consent to participate

Not applicable

\section{Competing interests}

The authors declare that they have no competing interests.

\section{Author details}

${ }^{1}$ Department of Forest Sciences, University of Helsinki, P.O. Box 27, Fl-00014 Helsinki, Finland. ${ }^{2}$ Häme University of Applied Sciences, P.O Box 230, FI-13100 Hämeenlinna, Finland. ${ }^{3}$ Natural Resources Institute Finland (Luke),

Latokartanonkaari 9, Fl-00790 Helsinki, Finland. 'Tampere University of Applied Sciences, PO Box 21, Fl-33521 Tampere, Finland. ${ }^{5}$ Finnish

Environment Institute, Latokartanonkaari 11, FI-00790 Helsinki, Finland.

Received: 10 June 2019 Accepted: 11 October 2019

Published online: 02 December 2019

\section{References}

Äijälä O, Koistinen A, Sved J, Vanhatalo K, Väisänen P (eds.). (2019). Metsänhoidon suositukset. Tapion julkaisuja. 252 p.

Aubry KB, Halpern CB, Maguire DA (2004) Ecological effects of variable-retention harvests in the northwestern United States: the DEMO study. For Snow Landsc Res 78:119-137

Baker SC, Read SM (2011) Variable retention silviculture in Tasmania's wet forests: ecological rationale, adaptive management and synthesis of biodiversity benefits. Aust For 74:218-232

Beese WJ, Deal J, Dunsworth BG, Mitchell SJ, Philpot T. (2019). Two decades of variable retention in British Columbia: a review of its implementation and effectiveness for biodiversity conservation. Ecol Process 8:33. doi.org/10.1186/ s13717-019-0181-9.

Berglund H, Jönsson MT, Penttilä R, Vanha-Majamaa I (2011) The effects of burning and dead-wood creation on the diversity of pioneer woodinhabiting fungi in managed boreal spruce forests. For Ecol Manage 261: 1293-1305

Chen J, Franklin JF, Spies TA (1995) Growing-season microclimatic gradients from clearcut edges into old-growth Douglas-fir forests. Ecol Appl 5:74-86

Core Team R (2018) R: a language and environment for statistical computing, Version 3.5.1. R Foundation for Statistical Computing. Vienna, Austria https:// www.R-project.org/

Craig A, Macdonald SE (2009) Threshold effects of variable retention harvesting on understory plant communities in the boreal mixedwood forest. For Ecol Manage 258:2619-2627

Fedrowitz K, Koricheva J, Baker SC, Lindenmayer DB, Palik B, Rosenvald R, Beese W, Franklin JF, Kouki J, Macdonald E, Messier C, Sverdrup-Thygeson A, 
Gustafsson L (2014) Can retention forestry help conserve biodiversity? A meta-analysis. J Appl Ecol 51:1669-1679

PEFC Finland. (2009). PEFC Finland Standard. Criteria for group certification. Level of a forestry centre or a forest management association. PEFC FI 1002:2009.

PEFC Finland. (2014). PEFC Finland Standard. Criteria for PEFC Forest Certification. PEFC FI 1002:2014.

PEFC Finland. (2019). https://pefc.fi/pefc-numeroina/ cited 16 May, 2019.

Finnish Forest Centre. (2019). Data of retention levels in private forests in 2013-2017, https://www.metsakeskus.fi/yksityismetsien-luonnonhoito, cited 6 June, 2019.

Finnish FSC Association. (2010). FSC Standard for Finland. Available at http:// finland.fsc.org/Dokumentit/FSC\%20Standard\%20for\%20Finland\%20 V11\%20APPROVED\%20210111.pdf.

Forestry Centre Tapio. (2013). Time series of the monitoring data on retention levels in private forests 1998-2012. Data provided by Forestry Centre Tapio 30 August, 2013.

Forsius M, Akujärvi A, Mattsson T, Holmberg M, Punttila P, Posch M, Liski J, Repo A, Virkkala R, Vihervaara P (2016) Modelling impacts of forest bioenergy use on ecosystem sustainability: Lammi LTER region, southern Finland. Ecol Indic 65:66-75

Franklin JF, Berg DF, Thornburg D, Tappeiner JC. (1997). Alternative silvicultural approaches to timber harvesting: variable retention harvest systems. Creating a Forestry for the 21st Century: The Science of Ecosystem Management: 111140.

Granath G, Kouki J, Johnson S, Heikkala O, Rodríguez A, Strengbom J (2018) Trade-offs in berry production and biodiversity under prescribed burning and retention regimes in boreal forests. J Appl Ecol 55:1658-1667

Gundersen VS, Frivold LH (2008) Public preferences for forest structures: a review of quantitative surveys from Finland, Norway and Sweden. Urb For Urb Green 7:241-258

Gustafsson L, Baker SC, Bauhus J, Beese WJ, Brodie A, Kouki J, Lindenmayer DB, Lõhmus A, Martínez Pastur G, Messier C, Neyland M, Palik B, SverdrupThygeson A, Volney WJA, Wayne A, Franklin JF (2012) Retention forestry to maintain multifunctional forests: a world perspective. BioScience 62:633-645.

Gustafsson L, Kouki J, Sverdrup-Thygeson A (2010) Tree retention as a conservation measure in clear-cut forests of northern Europe: a review of ecological consequences. Scand J For Res 25:295-308

Halpern CB, Halaj J, Evans SA, Dovčiak M (2012) Level and pattern of overstory retention interact to shape long-term responses of understories to timber harvest. Ecol Appl 22:2049-2064

Hänninen H, Koskela T, Kurttila M. (2008). Finnish family forest owners' retention tree management behaviour. In: Bergseng E, Delbeck G, Hoen HF (eds.) Scandinavian Forest Economics 42: Proceedings of the Biennial Meeting of the Scandinavian Society of Forest Economics, Lom, Norway, 6th-9th April 2008. Ås. pp. 344-360.

Hänninen H, Kurttila M, Koskela T (2010) Miten säästöpuut säilyvät uudistusaloilla? In: Koskela T, Hänninen R, Ovaskainen V (eds) Metsien monimuotoisuuden turvaamisen keinot ja yhteiskunnalliset vaikutukset (TUK) -tutkimusohjelman loppuraportti, Metlan työraportteja / Working Papers of the Finnish Forest Research Institute, vol 158, pp 35-38

Heikkala O, Martikainen P, Kouki J (2017) Prescribed burning is an effective and quick method to conserve rare pyrophilous forest-dwelling flat bugs. Insect Cons Diver 10:32-41

Heikkala O, Seibold S, Koivula M, Martikainen P, Müller J, Thorn S, Kouki J (2016) Retention forestry and prescribed burning result in functionally different saproxylic beetle assemblages than clear-cutting. For Ecol Manage 359:51-58

Heikkala O, Suominen M, Junninen K, Hämäläinen A, Kouki J (2014) Effects of retention level and fire on retention tree dynamics in boreal forests. For Ecol Manage 328:193-201

Heithecker TD, Halpern CB (2007) Edge-related gradients in microclimate in forest aggregates following structural retention harvests in western Washington. For Ecol Manage 248:163-173

Henttonen HM, Nöjd P, Suvanto S, Heikkinen J, Mäkinen H (2019) Large trees have increased greatly in Finland during 1921-2013, but recent observations on old trees tell a different story. Ecol Indic 99:118-129

Hyvärinen E, Juslén A, Kemppainen E, Uddström A, Liukko U-M (eds) (2019) Suomen lajien uhanalaisuus - Punainen kirja 2019 / The 2019 Red List of Finnish Species. Ympäristöministeriö \& Suomen ympäristökeskus / Ministry of the Environment \& Finnish Environment Institute, Helsinki, 703 p

Hyvärinen E, Kouki J, Martikainen P (2006) Fire and green-tree retention in conservation of red-listed and rare deadwood-dependent beetles in Finnish boreal forests. Cons Biol 20:1711-1719
Hyvärinen E, Kouki J, Martikainen P, Lappalainen H (2005) Short-term effects of controlled burning and green-tree retention on beetle (Coleoptera) assemblages in managed boreal forests. For Ecol Manage 212:315-332

Jääskeläinen K, Pykälä J, Rämä H, Vitikainen O, Haikonen V, Högnabba F, Lommi S, Puolasmaa A. (2010). Jäkälät - Lichens - Lichenes In: Rassi P, Hyvärinen E, Juslén A, Mannerkoski I (eds.), Suomen lajien uhanalaisuus 2010. The 2010 Red List of Finnish Species. Ympäristöministeriö ja Suomen ympäristökeskus, Ministry of the Environment and Finnish Environment Institute. p. 278-310.

Johnson S, Strengbom J, Kouki J (2014) Low levels of tree retention do not mitigate the effects of clearcutting on ground vegetation dynamics. For Ecol Manage 330:67-74

Junninen K, Penttilä R, Martikainen P (2007) Fallen retention aspen trees on clearcuts can be important habitats for red-listed polypores: a case study in Finland. Biodivers Cons 16:475-490

Kaila L, Martikainen P, Punttila P (1997) Dead trees left in clear-cuts benefit saproxylic Coleoptera adapted to natural disturbances in boreal forest. Biodivers Cons 6:1-18

Kaukonen M, Eskola T, Herukka I, Karppinen H, Karvonen L, Korhonen I, P. K, Ervola A (eds.). (2018). Metsähallitus Metsätalous Oy:n ympäristöopas. Metsähallitus Metsätalous Oy. 130 p.

Keto-Tokoi P, Kuuluvainen T. (2014). Primeval forests of Finland: cultural history, ecology and conservation. Maahenki. 302 p.

Korhonen KT, Auvinen A-P, Kuusela S, Punttila P, Salminen O, Siitonen J, Ahlroth P, Jäppinen J-P, Kolström T (2016) Biotalouskenaarioiden mukaisten hakkuiden vaikutukset metsien monimuotoisuudelle tärkeisiin rakennepiirteisiin. Luonnonvara- ja biotalouden tutkimus 51:1-36.

Korhonen KT, Ihalainen A, Ahola A, Heikkinen J, Henttonen HM, Hotanen J-P, Nevalainen S, Pitkänen J, Strandström M, Viiri H (2017) Suomen metsät 20092013 ja niiden kehitys 1921-2013. Luonnonvara- ja biotalouden tutkimus 59: $1-86$.

Kotiaho JS, Kouki J, Punttila P. (2006). Ongelmakohtia kuolleen puun ylläpidossa nykyisissä metsäekosysteemeissä. In: Horne P, Koskela T, Kuusinen M, Otsamo A, Syrjänen K (eds.), METSOn jäljillä - Etelä-Suomen metsien monimuotoisuusohjelman tutkimusraportti. Maa- ja metsätalousministeriö, ympäristöministeriö, Metsäntutkimuslaitos ja Suomen ympäristökeskus. p. 212-216.

Kouki J, Junninen K, Mäkelä K, Hokkanen M, Aakala T, Hallikainen V, Korhonen KT, Kuuluvainen T, Loiskekoski M, Mattila O, Matveinen K, Punttila P, Ruokanen I, Valkonen S, Virkkala R. (2018). Metsät. In: Kontula T, Raunio A (eds.), Suomen luontotyyppien uhanalaisuus 2018. Luontotyyppien punainen kirja. Osa 1 tulokset ja arvioinnin perusteet. Suomen ympäristö 5/2018. p. 171-201.

Kruys N, Fridman J, Götmark F, Simonsson P, Gustafsson L (2013) Retaining trees for conservation at clearcutting has increased structural diversity in young Swedish production forests. For Ecol Manage 304:312-321

Kurttila M, Hänninen H. (2006). Metsänomistajien tiedot monimuotoisuudesta ja säästöpuustosta. In: Horne P, Koskela T, Kuusinen M, Otsamo A, Syrjänen K (eds.), METSOn jäljillä - Etelä-Suomen metsien monimuotoisuusohjelman tutkimusraportti. Maa- ja metsätalousministeriö, ympäristöministeriö, Metsäntutkimuslaitos ja Suomen ympäristökeskus. p. 224-228.

Kuuluvainen T (2002) Natural variability of forests as a reference for restoring and managing biological diversity in boreal Fennoscandia. Silva Fenn 36:97-125

Kuuluvainen T (2009) Forest management and biodiversity conservation based on natural ecosystem dynamics in Northern Europe: The complexity challenge. Ambio 38:309-315

Kuuluvainen T, Siitonen J (2013) Fennoscandian boreal forests as complex adaptive systems. Properties, management challenges and opportunities. In: Messier C, Puettman KJ, Coates KD (eds) Managing forests as complex adaptive systems: building resilience to the challenge of global change. Earthscan, Abingdon, pp 244-268

Kuusinen M. (2006). Yksityismetsien luonnonhoidon laadun seurannan tulokset 1996-2005. In: Horne P, Koskela T, Kuusinen M, Otsamo A, Syrjänen K (eds.), METSOn jäljillä - Etelä-Suomen metsien monimuotoisuusohjelman tutkimusraportti. Maa- ja metsätalousministeriö, ympäristöministeriö, Metsäntutkimuslaitos ja Suomen ympäristökeskus. p. 229-234.

Laasasenaho J (1982) Taper curve and volume functions for pine, spruce and birch. Comm Inst For Fenn 108:1-74

Lindenmayer D, Franklin J (2002) Conserving forest biodiversity: a comprehensive multiscaled approach. Island Press, Washington DC, USA, $352 \mathrm{p}$

Lindenmayer DB, Franklin JF, Lõhmus A, Baker SC, Bauhus J, Beese W, Brodie A, Kiehl B, Kouki J, Martínez Pastur G, Messier C, Neyland M, Palik B, SverdrupThygeson A, Volney J, Wayne A, Gustafsson L (2012) A major shift to the 
retention approach for forestry can help resolve some global forest sustainability issues. Cons Lett 5:421-431

Martikainen P (2001) Conservation of threatened saproxylic beetles: significance of retained aspen Populus tremula on clearcut areas. Ecol Bull 49:205-218

Martínez Pastur G, Lencinas MV, Cellini JM, Peri PL, Soler ER (2009) Timber management with variable retention in Nothofagus pumilio forests of Southern Patagonia. For Ecol Manage 258:436-443

Matveinen K, Lilja-Rothsten S, Junninen K, Bäckman M, Eteläaho E, Kajander L, Kammonen A, Korhonen KT, Lindberg H, Loiskekoski M, Musta I, Nissinen M, Perkiö R, Punttila P, Sahi V, Syrjänen K, Tiitinen-Salmela S, Tonteri T. (2015) Metsäelinympäristöt [Forest habitats]. In: Kotiaho JS, Kuusela S, Nieminen E, Päivinen J (eds.), Elinympäristöjen tilan edistäminen Suomessa. ELITEtyöryhmän mietintö elinympäristöjen tilan edistämisen priorisointisuunnitelmaksi ja arvio suunnitelman kokonaiskustannuksista [In Finnish with an English summary: Improving the status of habitats in Finland - report of the ELITE working group on a prioritisation plan for improving the status of habitats and estimated total costs of the plan]. Suomen ympäristö [The Finnish Environment] 8/2015. p. 100-122.

McLeod, A. I. (2011). Kendall: Kendall rank correlation and Mann-Kendall trend test. https://CRAN.R-project.org/package=Kendall.

Metsäsertifioinnin standardityöryhmä. (2003). FFCS 1002-1:2003, Ryhmäsertifioinnin kriteerit metsäkeskuksen toimialueen tasolla. Metsäsertifioinnin standardityöryhmä 29.9.2003, 17 s.

Metsäsertifioinnin valmiusprojekti. (1998). Suomen metsäsertifiointijärjestelmän standardiluonnokset 19.11.1998. Metsäsertifioinnin valmiusprojekti. 103 s. + 2 liitettä.

Ministry of Agriculture and Forestry \& Ministry of the Environment (1994) New Environmental Programme for Forestry in Finland (confirmed by the Ministry of Agriculture and Forestry and the Ministry of the Environment). Helsinki, Finland, $63 \mathrm{p}$

Moen J, Rist L, Bishop K, Chapin FS, Ellison D, Kuuluvainen T, Petersson H, Puettmann KJ, Rayner J, Warkentin IG, Bradshaw CJA (2014) Eye on the taiga: removing global policy impediments to safeguard the boreal forest. Cons Lett 7:408-418

Mori AS, Kitagawa R (2014) Retention forestry as a major paradigm for safeguarding forest biodiversity in productive landscapes: a global metaanalysis. Biol Cons 175:65-73

Natural Resources Institute Finland. (2019). https://stat.luke.fi/en/ cited May 27 2019.

Nieminen A. (2006a). Metsäsertifiointi - SMS- ja FFCS kriteerien vertailu. In: Horne P, Koskela T, Kuusinen M, Otsamo A, Syrjänen K (eds.), METSOn jäljillä - EteläSuomen metsien monimuotoisuusohjelman tutkimusraportti. Maa- ja metsätalousministeriö, ympäristöministeriö, Metsäntutkimuslaitos ja Suomen ympäristökeskus. p. 273-275.

Nieminen A (2006b) Metsäsertifioinnin ekotehokkuus. Metlan työraportteja (Working Papers of the Finnish Forest Research Institute) 39:1-85

Oldén A, Ovaskainen O, Kotiaho JS, Laaka-Lindberg S, Halme P (2014) Bryophyte species richness on retention aspens recovers in time but community structure does not. PLoS ONE 9(4):e93786 https://doi.org/10.1371/journal. pone.0093786

Peltola A (ed.). (2014). Metsätilastollinen vuosikirja 2014 [Finnish Statistical Yearbook of Forestry]. SVT Maa-, metsä- ja kalatalous 2014 [Official Statistics of Finland: Agriculture, forestry and fishery]. Metsäntutkimuslaitos [Finnish Forest Research Institute]. $428 \mathrm{p}$.

Pommerening A, Murphy ST (2004) A review of the history, definitions and methods of continuous cover forestry with special attention to afforestation and restocking. Forestry 77:27-44

Puettmann KJ, Coates KD, Messier C (2008) A critique of silviculture - managing for complexity. Island Press, Washington DC, $189 \mathrm{p}$

Rosenvald R, Lõhmus A (2008) For what, when, and where is green-tree retention better than clear-cutting? A review of the biodiversity aspects. For Ecol Manage 255:1-15

Salomäki M (2005) Säästöpuut Isojoen Sahan avohakkuualueilla 2000-2004 [In Finnish with an English summary: retention tree dynamics in some clear-cuts of Southern Ostrobothnia in 2000-2004]. Pro gradu -tutkielma, Metsäympäristön hoidon ja suojelun laitos, Joensuun yliopisto, Metsätieteellinen tiedekunta.

Scott RE, Neyland MG, Baker SC (2019) Variable retention in Tasmania, Australia: trends over 16 years of monitoring and adaptive management. Ecol Process $8: 23$
Shorohova E, Sinkevich S, Kryshen A, Vanha-Majamaa I (2019) Variable retention forestry in European boreal forests in Russia. Ecol Process 8:34

Siitonen J (2012) Threatened saproxylic species. In: Stokland JN, Siitonen J, Jonsson BG (eds) Biodiversity in dead wood. Cambridge University Press, Cambridge, UK, pp 356-379

Simonsson P, Gustafsson L, Östlund L (2015) Retention forestry in Sweden: driving forces, debate and implementation 1968-2003. Scan J For Res 30: 154-173.

Soler RM, Schindler S, Lencinas MV, Peri PL, Martínez PG (2015) Retention forestry in southern Patagonia: multiple environmental impacts and their temporal trends. Int For Rev 17:231-243

FSC Suomi. (2018). Toimintakertomus 2018. FSC Suomi. 15 p

Suominen M, Junninen K, Heikkala O, Kouki J (2015) Combined effects of retention forestry and prescribed burning on polypore fungi. J Appl Ecol 52: $1001-1008$

Sverdrup H, Stjernquist I (2002) Introduction to the SUFOR Programme. In: Sverdrup H, Stjernquist I (eds) Developing principles and models for sustainable forestry in Sweden. Springer, Dordrecht, pp 1-12

Tapio M (1994) Luonnonläheinen metsänhoito. Metsänhoitosuositukset. Metsäkeskus Tapion julkaisu 6:1-72

The Board of the Finnish FSC Association (2005) The Draft FSC standard for Finland. In: Approved by the Board of the Finnish FSC Association at 17th February 2005. Association, Finnish FSC, $46 \mathrm{p}$

Tomppo E, Henttonen H, Tuomainen T (2001) Valtakunnan metsien 8. inventoinnin menetelmä ja tulokset metsäkeskuksittain Pohjois-Suomessa 1992-94 sekä tulokset Etelä-Suomessa 1986-92 ja koko maassa 1986-94. Metsätieteen aikakauskirja 1B(2001):99-248

Vanha-Majamaa I, Jalonen J (2001) Green tree retention in Fennoscandian forestry. Scand J For Res Suppl 3:79-90

Vanha-Majamaa I, Lilja S, Ryömä R, Kotiaho JS, Laaka-Lindberg S, Lindberg H, Puttonen P, Tamminen P, Toivanen T, Kuuluvainen T (2007) Rehabilitating boreal forest structure and species composition in Finland through logging, dead wood creation and fire: The EVO experiment. For Ecol Manage 250:77-88

Vanha-Majamaa I, Shorohova E, Kushnevskaya H, Jalonen J (2017) Resilience of understory vegetation after variable retention felling in boreal Norway spruce forests - A ten-year perspective. For Ecol Manage 393:12-28

Wallenius T, Kuuluvainen T, Vanha-Majamaa I (2004) Fire history in relation to site type and vegetation in eastern Fennoscandia, Russia. Can J For Res 34:14001409

Work TT, Spence JR, Volney WJA, Morgantini LE, Innes JL (2003) Integrating biodiversity and forestry practices in western Canada. For Chron 79:906-916

\section{Publisher's Note}

Springer Nature remains neutral with regard to jurisdictional claims in published maps and institutional affiliations.

\section{Submit your manuscript to a SpringerOpen ${ }^{\circ}$ journal and benefit from:}

- Convenient online submission

- Rigorous peer review

- Open access: articles freely available online

- High visibility within the field

- Retaining the copyright to your article

Submit your next manuscript at $>$ springeropen.com 